\title{
Korelasi Kadar 8-Hydroxy-2-Deoxyguanosine (8-OHdG) Serum dengan Derajat Defisit Neurologis pada Strok Iskemik
}

\author{
Liza, ${ }^{1}$ Ida Parwati, ${ }^{1}$ Andi Basuki Prima Birawa, ${ }^{2}$ Sylvia Rachmayati ${ }^{1}$ \\ ${ }^{1}$ Departemen Patologi Klinik Fakultas Kedokteran Universitas Padjadjaran, ${ }^{2}$ Departemen Ilmu \\ Penyakit Saraf Fakultas Kedokteran Universitas Padjadjaran
}

\begin{abstract}
Abstrak
Peningkatan stres oksidatif, sekresi radikal bebas pada strok iskemik dapat merusak inti sel neuron di otak. Peningkatan kadar 8-hydroxy-2-deoxyguanosine (8-OHdG) serum pada strok iskemik yang merupakan hasil interaksi radikal bebas dengan gugus C8 basa guanin menandakan kerusakan sel neuron otak yang tercermin pada penilaian defisit neurologis menggunakan skor The National Institutes of Health Stroke Scale (NIHSS). Tujuan penelitian ini untuk mengetahui korelasi kadar 8-OHdG serum dengan derajat defisit neurologis menggunakan skor NIHSS. Bentuk penelitian adalah observasional dengan desain penelitian potong lintang. Penelitian dilakukan di RSUP Dr. Hasan Sadikin Bandung pada bulan Agustus 2013 hingga Januari 2014. Subjek penderita stroke iskemik onset akut berdasarkan CT-scan. Analisis statistik menggunakan Uji Kruskal-Wallis, Uji korelasi Rank Spearman. Sebanyak 72 subjek penelitian diperoleh median kadar 8-OHdG dalam serum dengan defisit neurologis ringan $3,9 \mathrm{ng} / \mathrm{mL}(3,3-12,0 \mathrm{ng} / \mathrm{mL})$, sedang $23 \mathrm{ng} / \mathrm{mL}(8,0-51,0 \mathrm{ng} / \mathrm{mL})$, berat $77,5 \mathrm{ng} / \mathrm{mL}(54,0-97,0 \mathrm{ng} / \mathrm{mL})$. Korelasi kadar 8-OHdG serum dengan derajat defisit neurologis $r_{s}=0,912(p<0,001)$. Simpulan, kadar 8-OHdG dalam serum pada strok iskemik berkorelasi positif sangat kuat dengan derajat defisit neurologis, hal ini dapat dipertimbangkan untuk digunakan pada keadaan ketidaksesuaian antara gambaran CT-scan dan klinis atau pada fasilitas kesehatan yang tidak mempunyai CT-scan. [MKB. 2014;46(3):177-82]
\end{abstract}

Kata kunci: Defisit neurologis, strok iskemik, 8-OHdG serum

\section{Correlation between Serum 8-Hydroxy-2-Deoxyguanosine (8-OHdG) and Neurological Deficits in Ischemic Stroke}

\begin{abstract}
Increased oxidative stress and free radicals can cause neuron cell damage. Serum 8-hydroxy-2-deoxyguanosine (8-OHdG) concentration is the result of free radical interactions with cluster C8 guanine bases, which is used to assess the degree of neuron cells damage and the oxidative stress levels. Increased serum 8-OHdG concentration indicating brain cells damage is reflected in neurological deficits based on the The National Institutes of Health Stroke Scale (NIHSS). The aim of this study was to determine the correlation between serum 8-OHdG concentration and the degree of neurological deficit by NIHSS. This was an observational cross-sectional study. Seventy-two patients with acute ischemic stroke who visited Dr. Hasan Sadikin General Hospital Bandung during the period of August 2013 to January 2014 were enrolled. Statistical analysis was performed using Kruskal-Wallis test and rank Spearman's correlation test. The mild neurological deficit median serum 8-OHdG concentrations was 3.9 $\mathrm{ng} / \mathrm{mL}(3.3-12.0 \mathrm{ng} / \mathrm{mL})$, moderate was $23 \mathrm{ng} / \mathrm{mL}(8.0-51.0 \mathrm{ng} / \mathrm{mL})$, and severe was $77.5 \mathrm{ng} / \mathrm{mL}(54.0-97.0 \mathrm{ng} /$ $\mathrm{mL})$. Correlation of serum $8-\mathrm{OHdG}$ concentration with neurological deficits in acute ischemic stroke $\mathrm{r}=0.912$ $(\mathrm{p}<0.001)$. In conclusion, serum $8-\mathrm{OHdG}$ have a strong meaningful positive correlation with neurological deficits. Serum 8-OHdG concentration may be considered to be use in the assessment of discrepancy between CT scan and clinical symptoms and in health facilities with no CT scan facility. [MKB. 2014;46(3):177-82]
\end{abstract}

Key words: Ischemic stroke, neurological deficits, serum 8-OHdG

Korespondensi: Liza, dr., Departemen Patologi Klinik, Fakultas Kedokteran Universitas Padjadjaran/Rumah Sakit Dr. Hasan Sadikin Bandung, mobile081321946526,e-mail liza_doc@yahoo.com 


\section{Pendahuluan}

Sumbatan pembuluh darah otak mengakibatkan penurunan oksigen. Akibat penurunan kadar oksigen akan terjadi keadaan iskemia. Iskemia di otak meningkatkan prooksidan (radikal bebas) yang akan memicu stres oksidatif sehingga dapat menyebabkan kerusakan dan kematian sel saraf otak yang akan berpengaruh pada fungsi otak secara keseluruhan serta menyebabkan defisit neurologis. ${ }^{1,2}$

Defisit neurologis adalah gangguan fungsional tubuh karena penurunan fungsi otak, saraf, dan otot. The National Institutes of Health Stroke Scale (NIHSS) merupakan skala untuk menilai defisit neurologis dan perburukan luaran penyakit strok iskemik berdasarkan motorik penderita strok iskemik yang bersifat subjektif. Penilaian defisit neurologis antara lain tingkat kesadaran, gerakan mata, lapang pandangan mata, paresis oto wajah, motorik lengan dan tungkai, ataksia anggota gerak, sensorik, bahasa, disartria, serta pengabaian \& inatensi (neglect). Hasil penilaian NIHSS berupa skor yaitu $<5$ : defisit neurologis ringan, 6-14: defisit neurologis sedang, 15-24: defisit neurologis berat, $\geq 25$ : defisit neurologis sangat berat.

Strok diagnosisnya ditegakkan berdasarkan anamnesis, pemeriksaan fisis, serta pemeriksaan penunjang. Pemeriksaan baku emas strok adalah computed tomography scanning (CT-scan) kepala yang dapat membedakan strok iskemik dengan strok perdarahan. Pemeriksaan CT-scan kepala dapat menilai kerusakan struktural otak tetapi tidak dapat menilai kerusakan seluler otak secara kuantitatif, gambarannya bergantung pada resolusi mesin, ukuran dan lokasi lesi, serta waktu pemeriksaan, sehingga dapat menyebabkan ketidaksesuaian antara gambaran CT-scan dan gejala klinis penderita strok iskemik. Keberadaan pemeriksaan penunjang yang dapat menilai kerusakan otak secara kuantitatif pada penderita strok iskemik diharapkan dapat membantu klinisi mengatasi hal tersebut.

Saat ini sudah terdapat pemeriksaan penunjang yaitu berupa penanda stres oksidatif 8-hydroxy2-deoxyguanosine (8-OHdG) dalam serum yang kadarnya dapat diukur secara kuantitatif, bersifat objektif, dapat membantu mengetahui tingkat kerusakan sel otak akibat iskemia, memprediksi tingkat stres oksidatif, dan prognosis penderita strok iskemik. Kadar 8-OHdG dalam serum yang tinggi menandakan kerusakan otak yang berat dan akan tercermin pada defisit neurologis yang terjadi akibat strok iskemik. ${ }^{1-3}$

Radikal bebas yang terbentuk waktu terjadi iskemia otak akan melakukan interaksi dengan basa guaninnya pada gugus $\mathrm{C} 8$ yang merupakan target utama. Kemudian, guanin akan teroksidasi menyebabkan terbentuknya 8-oxo-Gua (bentuk nukleotida) yang dapat menyebabkan kegagalan DNA repair. 8-oxoguanine DNA glycosylase 1 (OGG1) adalah enzim glikosilase DNA yang berperan pada base excision repair (BER). Enzim OGG1 akan memotong/eksisi 8-oxo-Gua (bentuk nukleotida) menjadi 8-OHdG (bentuk nukleosida). 8-hydroxy-2-deoxyguanosine yang terlepas dari rantai DNA tidak memerlukan metabolisme lebih lanjut, masuk ke dalam sirkulasi darah sehingga dapat terdeteksi di dalam serum penderita strok iskemik. . $^{4-6}$

Terdapat beberapa penanda stres oksidatif pada strok iskemik, tetapi kebanyakan penanda tersebut tidak dapat mencapai tahapan klinis yang signifikan. Keunggulan pemeriksaan kadar 8-OHdG serum adalah sensitif, dihasilkan dalam jumlah signifikan, bersifat spesifik DNA, dapat dideteksi oleh berbagai metode pemeriksaan salah satunya dengan metode mikro the enzyme-linked immunosorbent assay (ELISA). Keuntungan metode mikro ELISA itu adalah pengerjaannya yang cepat, mudah, murah, menggunakan sedikit peralatan, memberikan hasil akurat. ${ }^{3}$

Penelitian oleh Brea dkk. ${ }^{5}$ pada tahun 2009 di Spanyol dan Nakajima dkk. ${ }^{3}$ pada Juli 2007Februari 2008 di Osaka mendapatkan hasil bahwa penanda 8-OHdG merupakan penanda stres oksidatif yang dapat digunakan untuk mengetahui derajat kerusakan sel otak serta menilai luaran klinis pada penderita strok iskemik. Berdasarkan uraian tersebut, maka peneliti tertarik untuk mengetahui korelasi antara kadar 8-OHdG serum dan derajat defisit neurologis pada penderita strok iskemik di Rumah Sakit Dr. Hasan Sadikin Bandung, sehingga diharapkan dapat membantu klinisi menilai derajat kerusakan otak akibat strok iskemik, memprediksi stres oksidatif, serta mengetahui prognosis penderita strok iskemik.

\section{Metode}

Penelitian ini merupakan penelitian observasional dengan rancangan secara potong lintang (crosssectional study). Subjek penelitian ini direkrut secara consecutive admission sampling. Analisis statistik awal memakai uji normalitas dengan uji Kolmogorov-Smirnov untuk menguji normalitas data. Penelitian ini memiliki data kadar 8-OHdG serum yang tidak berdistribusi normal, sehingga digunakan uji Kruskal-Wallis. Hasil uji statistik bermakna dengan nilai $\mathrm{p}<0,05$. Analisis korelasi kadar 8-OHdG serum dengan derajat defisit neurologis memakai Uji korelasi Rank Spearman.

Penelitian dilakukan di RS Dr. Hasan Sadikin pada bulan Agustus 2013 hingga Januari 2014. 
Subjek penelitian adalah penderita strok iskemik yang datang berobat ke Unit Gawat Darurat, Poliklinik Penyakit Saraf atau berada di ruang perawatan Penyakit Sarafdi RS Dr. Hasan Sadikin Bandung dan telah menandatangani persetujuan ikut dalam penelitian (informed consent). Kriteria inklusi adalah penderita yang telah didiagnosis strok iskemik berdasarkan hasil pemeriksaan CTscan. Kriteria eksklusi adalah penderita dengan penyakit keganasan.

Penilaian skor NIHSS dan juga pengambilan darah untuk pemeriksaan kadar 8-OHdG serum dilakukan pada waktu subjek penelitian datang ke rumah sakit. Darah sebanyak $3 \mathrm{~mL}$ diperoleh dengan cara flebotomi yang dilakukan pada vena kubiti dengan menggunakan disposable syringe. Darah dimasukkan ke dalam tabung vacutainer, didiamkan selama 30 menit dengan posisi tegak lurus sampai terjadi pembekuan untuk selanjutnya disentrifugasi dengan kecepatan $3.000 \mathrm{~g}$ selama sepuluh menit. Serum yang terbentuk dipisahkan dan dimasukkan ke dalam tabung plastik mikro/ microtube dan disimpan pada suhu $-80^{\circ} \mathrm{C}$ sampai diperoleh jumlah sampel yang telah ditentukan untuk selanjutnya dilakukan pemeriksaan kadar 8-OHdG dalam serum secara bersamaan.

Pemeriksaan kadar 8-OHdG di dalam serum pada penelitian ini menggunakan metode mikro ELISA. Kadar 8-OHdG serum stabil selama 3 hari pada suhu $25{ }^{\circ} \mathrm{C}$, stabil selama 5 hari bila disimpan pada suhu $2-8{ }^{\circ} \mathrm{C}$, stabil selama 1 bulan pada suhu $-20^{\circ} \mathrm{C}$ dan stabil selama 3 bulan pada suhu $-80{ }^{\circ} \mathrm{C} .{ }^{8,9}$

\section{Hasil}

Hasil penelitian ini meliputi karakteristik subjek penelitian, analisis, dan korelasi kadar $8-\mathrm{OHdG}$ serum dengan derajat defisit neurologis. Pada penelitian ini tidak ditemukan strok dengan defisit neurologis sangat berat, sehingga pada analisis selanjutnya defisit neurologis itu dibagi menjadi kelompok ringan, sedang, dan berat.

Strok iskemik itu lebih banyak terjadi pada perempuan $(58 \%)$. Berdasarkan kelompok usia diperoleh hasil paling banyak subjek penelitian kategori usia $\geq 45$ tahun. Berdasarkan onset strok yakni jangka waktu pada awal berlangsungnya serangan strok iskemik sampai penderita datang ke Rumah Sakit Dr. Hasan Sadikin Bandung diperoleh hasil paling banyak $<24$ jam. Faktor risiko strok terbanyak yang terdapat pada subjek penelitian adalah hipertensi (Tabel 1).

Kadar $8-\mathrm{OHdG}$ serum itu ternyata berbeda bermakna secara statistik pada masing-masing kelompok derajat defisit neurologis ringan, sedang, dan berat $(p<0,001)$. Analisis selanjutnya
Tabel 1 Karakteristik Subjek Penelitian $(\mathrm{n}=72)$

\begin{tabular}{lc}
\hline \multicolumn{1}{c}{ Variabel } & n (\%) \\
\hline Onset strok (jam) & $38(53)$ \\
$<24$ & $34(47)$ \\
$\geq 24$ & \\
Faktor risiko & $59(82)$ \\
Hipertensi & $41(57)$ \\
Dislipidemia & $27(37)$ \\
Penyakit jantung & $25(35)$ \\
Merokok & $19(26)$ \\
Diabetes melitus & \\
Jenis kelamin & $30(42)$ \\
Laki-laki & $42(58)$ \\
Perempuan & \\
Usia (tahun) & $9(13)$ \\
$<45$ & $63(87)$ \\
$\geq 45$ & \\
Jumlah faktor risiko & $16(22)$ \\
1 & $48(67)$ \\
$2-3$ & $8(11)$ \\
$>3$ &
\end{tabular}

Keterangan: $n=$ jumlah subjek penelitian

dengan menggunakan analisis post hoc untuk Uji Kruskal-Wallis adalah Uji Mann-Whitney diperoleh hasil sebagai berikut: kelompok defisit neurologis ringan dan sedang $(p<0,001)$, ringan dan berat $(p<0,001)$, sedang dan berat $(p<0,001)$. Dengan demikian, terdapat perbedaan kadar 8-OHdG dalam serum pada kelompok defisit neurologis ringan dan sedang, ringan dan berat, sedang dan berat yang secara statistik berbeda bermakna (Tabel 2)

Tabel 3 dan Gambar menunjukkan korelasi positif yang baik dan juga searah antara kadar 8-OHdG serum dan derajat defisit neurologis pada strok iskemik dengan nilai $r=0,912 ; p<0,001$ yang sangat bermakna secara statistik. Hal ini menunjukkan makin tinggi kadar 8-OHdG serum, makin berat derajat defisit neurologisnya.

\section{Pembahasan}

Pada penelitian ini tidak ditemukan strok dengan defisit neurologis sangat berat, sehingga pada analisis selanjutnya defisit neurologis tersebut dibagi menjadi kelompok ringan, sedang, dan berat. Semua data subjek penelitian dicatat di 
Liza: Korelasi Kadar 8-Hydroxy-2-Deoxyguanosine (8-OHdG) Serum dengan Derajat Defisit Neurologis pada Strok Iskemik

Tabel 2 Kadar 8-OHdG Serum pada Derajat Defisit Neurologis Ringan, Sedang, Berat

\begin{tabular}{lcccc}
\hline \multirow{2}{*}{$\begin{array}{c}\text { Kadar 8-OHdG } \\
\begin{array}{c}\text { Serum } \\
(\mathbf{n g} / \mathbf{m L})\end{array}\end{array}$} & $\begin{array}{c}\text { Ringan } \\
(\mathbf{n}=\mathbf{3 5})\end{array}$ & $\begin{array}{c}\text { Sedang } \\
(\mathbf{n = 2 5})\end{array}$ & $\begin{array}{c}\text { Berat } \\
(\mathbf{n}=\mathbf{1 2})\end{array}$ & Nilai $\mathbf{p}$ \\
\hline Median & 3,9 & 23 & 77,5 & $\mathrm{X}_{\mathrm{K}-\mathrm{W}}^{2}=59,067$ \\
Minimum-maksimum & $3,3-12,0$ & $8,0-51,0$ & $54,0-97,0$ & $\mathrm{p}<0,001$ \\
\hline
\end{tabular}

Keterangan: $\mathrm{X}_{\mathrm{K}-\mathrm{W}}^{2}=$ Uji Kruskal-Wallis; bermakna bila $\mathrm{p}<0,05$

dalam stroke registry.

Hasil penelitian ini menunjukkan penderita strok iskemik lebih banyak pada jenis kelamin perempuan dan usia $\geq 45$ tahun. Sebagian besar perempuan pada penelitian ini telah berusia lebih dari 50 tahun dan telah mengalami menopause. Masa menopause itu mengakibatkan penurunan kadar hormon estrogen yang seharusnya berfungsi memberikan proteksi pada proses aterosklerosis. Penurunan hormon estrogen dapat memudahkan proses aterosklerosis dan meningkatkan risiko strok. ${ }^{7,3}$ Risiko strok meningkat sejak usia 45 tahun baik pada laki-laki ataupun perempuan. Keadaan ini dapat terjadi karena sejalan dengan bertambahnya usia terjadi proses degenerasi yang akan meningkatkan proses aterosklerosis yang disebabkan penimbunan plak di dalam pembuluh darah, sehingga pembuluh darah akan mengalami penyempitan. ${ }^{10}$ Hasil penelitian ini menunjukkan usia subjek penelitian tidak berbeda bermakna secara statistik $(\mathrm{p}=0,591)$.

Faktor risiko strok terbanyak pada penelitian ini yaitu hipertensi sebanyak $82 \%$. Penelitian ini menunjukkan bahwa antara kadar $8-\mathrm{OHdG}$ serum dan faktor risiko hipertensi tidak berbeda bermakna $(p=0,491)$. Kejadian strok akan semakin besar bila tekanan darah semakin tinggi. Tekanan darah yang tinggi menyebabkan kerusakan pada dinding pembuluh darah. Kerusakan pembuluh darah itu akan mengaktifkan sistem pembekuan darah melalui jalur intrinsik maupun ekstrinsik, yang akan menghasilkan trombin. Trombin akan mengubah fibrinogen menjadi fibrin yang akan menstabilkan massa trombosit sehingga terbentuk

Tabel 3 Korelasi Kadar 8-OHdG Serum dengan Derajat Defisit Neurologis

\begin{tabular}{lcccc}
\hline \multirow{2}{*}{ Korelasi } & \multicolumn{3}{c}{ Defisit Neurologis } \\
\cline { 2 - 5 } & $\begin{array}{c}\text { Keseluruhan Defisit } \\
\text { Neurologis }\end{array}$ & Ringan & Sedang & Berat \\
\hline Kadar 8-OHdG serum & $\mathrm{r}=0,912$ & $\mathrm{r}_{\mathrm{s}}=0,933$ & $\mathrm{r}=0,975$ & $\mathrm{r}=0,968$ \\
$\mathrm{p}$ & $\mathrm{p}<0,001$ & $\mathrm{p}<0,001$ & $\mathrm{p}<0,001$ & $\mathrm{p}<0,001$ \\
\hline
\end{tabular}

Keterangan: $r_{s}=$ korelasi rank Spearman's

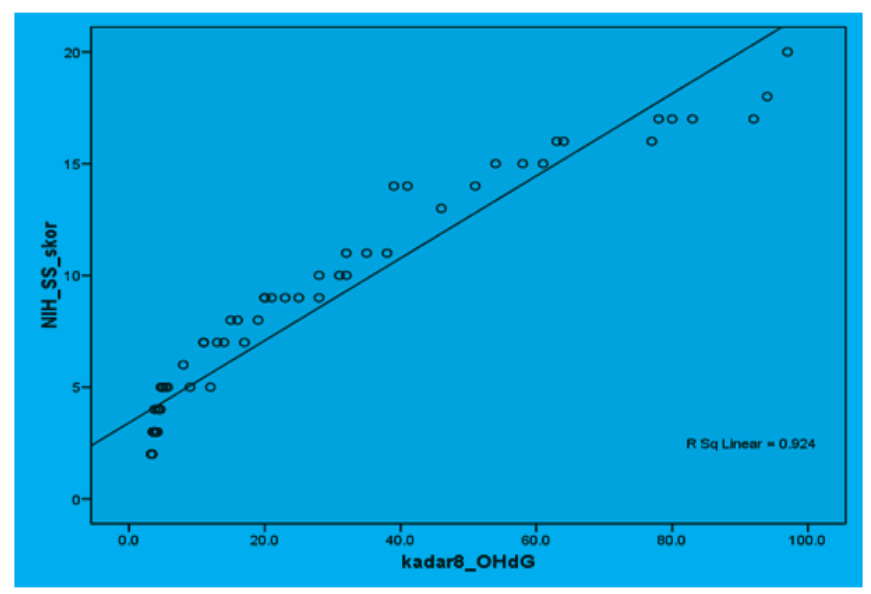

Gambar Korelasi Kadar 8-OHdG Serum dengan Skor NIHSS 
trombus. ${ }^{11}$ Trombus yang terjadi dapat terlepas, sehingga menyebabkan penyumbatan pembuluh darah otak yang merupakan penyebab strok.

Produksi radikal bebas pada hipertensi akan meningkat karena aktivasi reseptor angiotensin tipe I (ATI) oleh angiotensin II sehingga akan mengaktivasi NADPH oksidase dan superoxide. Anion superoxide dapat bereaksi dengan nitric oxide, sebagai akibatnya terbentuk peroksinitrit yang merupakan radikal bebas sangat kuat. Radikal bebas dalam jumlah yang banyak akan menyebabkan teroksidasinya protein, lipid, DNA secara ireversibel meningkatkan kadar $8-\mathrm{OHdG}$ serum. ${ }^{12-15}$

Kadar 8-OHdG serum pada onset strok $<24$ jam dan onset strok $\geq 24$ jam tidak bermakna secara statistik $(\mathrm{p}=0,561)$. Kadar $8-\mathrm{OHdG}$ serum akan terus meningkat dalam 3-4 jam. ${ }^{12,16}$ Mizukoshi dkk. ${ }^{16}$ menyatakan kadar $8-\mathrm{OHdG}$ tetap meningkat sampai pada hari kelima strok iskemik onset akut, setelah itu kadarnya akan menurun. Beberapa penelitian sebelumnya mengungkapkan bahwa kadar 8-OHdG serum meningkat pada penyakit yang berhubungan dengan stres oksidatif seperti penyakit jantung koroner, hipertensi, diabetes melitus, dislipidemia, dan juga merokok. ${ }^{3,17-19}$ Apbila keadaan klinis tersebut terdapat semakin banyak pada penderita strok iskemik, maka kadar 8-OHdG serum akan semakin meningkat.

Median kadar 8-OHdG serum pada defisit neurologis ringan $3,9 \mathrm{ng} / \mathrm{mL}(3,3-12,0 \mathrm{ng} / \mathrm{mL})$, sedangkan pada defisit neurologis sedang $23 \mathrm{ng} /$ $\mathrm{mL}(8,0-51,0 \mathrm{ng} / \mathrm{mL})$. Bila dilakukan penelusuran lebih lanjut, terdapat satu orang subjek penelitian dengan kadar $8-\mathrm{OHdG}$ serum sebesar $8 \mathrm{ng} / \mathrm{mL}$ menunjukkan defisit neurologis sedang. Subjek penelitian tersebut hanya mempunyai satu faktor risiko yaitu hipertensi. Terdapat satu orang subjek penelitian dengan kadar 8-OHdG serum $9 \mathrm{ng} / \mathrm{mL}$ menunjukkan defisit neurologis ringan, jumlah faktor risiko dua yaitu hipertensi dan merokok. Terdapat orang subjek penelitian dengan kadar 8-OHdG serum $12 \mathrm{ng} / \mathrm{mL}$ menunjukkan defisit neurologis ringan, jumlah faktor risiko dua yaitu hipertensi dan dislipidemia. Hal ini menunjukkan semakin banyak jumlah faktor risiko subjek penelitian, semakin tinggi kadar 8-OHdG serum. Ketidaksesuaian antara kadar 8-OHdG serum dan derajat defisit neurologis ini kemungkinan karena pemeriksaan defisit neurologis menggunakan skala NIHSS yang bersifat subjektif.

Hasil penelitian ini memperlihatkan bahwa kadar 8-OHdG serum berbeda bermakna secara statistik pada masing-masing kelompok derajat defisit neurologis ringan, sedang, dan berat $(p<0,001)$. Semakin tinggi kadar $8-\mathrm{OHdG}$ serum maka defisit neurologisnya semakin berat. Hal ini menggambarkan bahwa semakin tinggi tingkat kerusakan otak serta tingkat stres oksidatif akibat strok iskemik, maka kadar 8-OHdG serum akan meningkat dan luaran klinis penderita strok yang dinilai berdasarkan skala NIHSS akan menunjukkan defisit neurologis yang berat.

Hasil penelitian ini menunjukkan terdapat korelasi positif antara kadar $8-\mathrm{OHdG}$ serum dan derajat defisit neurologis $(r=0,912 ; p<0,001)$. $\mathrm{Hal}$ ini menunjukkan bahwa peningkatan kadar 8-OHdG serum akibat pembentukan radikal bebas pada strok iskemik berkorelasi dengan luaran klinis penderita strok iskemik yang dinilai dari derajat defisit neurologis berdasarkan skala NIHSS. Kadar 8-OHdG di dalam serum dapat menjadi suatu penanda untuk membantu menilai kerusakan otak yang diakibatkan strok iskemik serta membantu menilai perburukan luaran klinis penderita strok iskemik.

Hasil penelitian ini mempunyai keterbatasan yaitu penanda 8 -OHdG serum yang merupakan penanda stres oksidatif, bersifat kurang stabil, dan dapat dipengaruhi oleh berbagai faktor risiko strok iskemik seperti hipertensi, diabetes melitus, penyakit jantung koroner, dislipidemia, dan juga merokok.

Hasil penelitian mendapatkan korelasi positif sangat kuat dan bermakna antara kadar 8-OHdG dalam serum dan derajat defisit neurologis pada strok iskemik. Kadar 8-OHdG serum yang tinggi pada strok iskemik menunjukkan derajat defisit neurologis yang makin berat. Berdasarkan hasil penelitian ini, maka kadar 8-OHdG serum dapat dipertimbangkan untuk dipergunakan membantu menilai derajat kerusakan sel neuron di otak terutama bila terdapat ketidaksesuaian antara gambaran CT-scan dan klinis atau pada fasilitas kesehatan yang tidak mempunyai CT-scan.

\section{Daftar Pustaka}

1. Brouns R, De Deyn PP. The complexity of neurobiological processes in acute ischemic stroke. Clin Neurol Neurosurg. 2009;111(6): $483-95$.

2. Brouns R, De Smedt A, Van Hooff RJ, Moens M, De Keyser J. Biochemical pathways and their clinical applications in acute ischemic stroke. P Belg Roy Acad Med. 2012;1: $112-26$.

3. Nakajima $H$, Unoda $K$, Ito $T$, Kitaoka $H$, Kimura F, Hanafusa T. The relation of urinary $8-\mathrm{OHdG}$, a marker of oxidative stress to dna, and clinical outcomes for ischemic stroke. Open Neurol J. 2012;6:51-7.

4. Ock CY, Kim EH, Choi DJ, Lee HJ, Hahm KB, Chung MH. 8-Hydroxydeoxyguanosine: not mere biomarker for oxidative stress, 
but remedy for oxidative stress-implicated gastrointestinal diseases. World J Gastroenterol. 2012;18(4):302-8.

5. Brea D, Roquer J, Serena J, Segura T, Castillo J. Oxidative stress markers are associated to vascular recurrence in non-cardioembolic stroke patients non-treated with statins. BMC Neurol. 2012;12(65):1-8.

6. Halliwell B, Whiteman M. Measuring reactive species and oxidative damage in vivo and in cell culture: how should you do it and what do the results mean? Br J Pharmacol. 2004;142:231-55.

7. Aggarwal A, Aggarwal P, Khatak M, Khatak S. cerebral ischemic stroke: sequels of cascade. Intern J Pharma Bio Sci. 2010;1(3):1-24.

8. Chen H, Yoshioka H, Kim GS, Jung JE, Okami N, Sakata H, dkk. Oxidative stress in ischemic brain damage: mechanisms of cell death and potential molecular targets for neuroprotection. Antiox Redox Signal. 2011;14(8):1505-17.

9. Jureau A. Acute cerebral ischemia and oxidative stress. Romanian J Neurol. 2008; VII(2):45-56.

10. Genestra M. Oxyl radical, redox-sensitive signalling cascades and antioxidants. Cellular Signalling. 2007;19:1807-19.
11. Valavanidis A, Vlachogianni T, Fiotakis C. 8-hydroxy-2-deoxyguanosine $\quad$ (8-OHdG): a critical biomarker of oxidative stress and carcinogenesis. J Environ Sci Health C Environ Carcinog Ecotoxicol Rev. 2009; 27(2):120-39.

12. Vogiatzi G, Tousoulis D, Stefanadis C. The role of oxidative stress in atherosclerosis. Hellenic J Cardiol. 2009;50:402-9.

13. Mahmoudi M, Mercer J, Bennett M. DNA damage and repair in atherosclerosis. Cardiovascular Research. 2006;71:259-68.

14. Subash P, Gurumurthy P, Sarasabharathi A, Cherian K. Urinary 8-OHdG: a marker of oxidative stress to DNA and total antioxidant status in essential hypertension with South Indian population. Indian $\mathrm{J}$ Clin Biochem. 2010;25(2):127-32.

15. Rodrigo R, Libuy M, Feliu F, Hasson D. Oxidative stress-related biomarkers in essential hypertension and ischemiareperfusion myocardial damage. Disease Markers. 2013;35(6):773-90.

16. Mizukoshi G, Katsura KI, Watanabe M, Katayama Y. Evaluation of therapeutic efficacy of free radical scavenger in patients with ischemic stroke. Cerebral Blood Flow Metab. 2006;18:53-60. 